DOI 10.37882/2223-2982.2021.02.38

\title{
АНАЛИЗ ПРОЦЕССА ВЗАИМОДЕЙСТВИЯ КОММУНИКАНТОВ В ПЕРЕГОВОРАХ (НА МАТЕРИАЛЕ АНГЛОЯЗЫЧНЫХ ХУДОЖЕСТВЕННЫХ ФИЛЬМОВ)
}

\section{ANALYSIS OF THE PROCESS \\ OF INTERACTION OF COMMUNICANTS \\ IN THE NEGOTIATIONS (BASED ON THE MATERIAL OF ENGLISH-LANGUAGE FEATURE FILMS)}

\section{T. Shikhalkina}

Summary: This article analyzes the process of interaction of partners in negotiations using the classification of forms of influence by R. Bales and based on the material of English-language feature films. The article substantiates the idea that this format of analysis provides a basis for a deeper consideration of the mechanisms of successful negotiations. Based on the analysis model, the main behavioral manifestations of communicants in situations taken from feature films are considered. In conclusion, it is settled that this approach to the analysis of negotiation situations illustrates a wide range of behaviors, which allows to effectively defend your position and successfully conduct negotiations in the future.

Keywords: negotiations, communication, analysis of the interaction process, forms of influence, feature film.

\author{
Шихалкина Татьяна Григорьевна \\ Аспирант, Московский государственный \\ университет им. М.В. Ломоносова \\ shikhalkina@gmail.com
}

Аннотация: В данной статье проводится анализ процесса интеракции партнеров в переговорах с применением классификации форм воздействия Р. Бейлза и на материале англоязычных художественных фильмов. В статье обосновывается идея 0 том, что такой формат анализа дает основание глубже рассматривать механизмы ведения успешных переговоров. На основании модели анализа рассматриваются основные поведенческие проявления коммуникантов в ситуациях, взятых из художественных фильмов. В заключении сделаны выводы 0 том, что данный подход к анализу ситуаций переговоров иллюстрирует широкий круг форм поведения, что позволяет в будущем эффективно отстаивать свою позицию и успешно проводить переговоры.

Ключевые слова: переговоры, коммуникация, анализ процесса взаимодействия, формы воздействия, художественный фильм.
$\mathrm{O}$ дной из тенденций современного общества является растущая важность умения налаживать и поддерживать контакты. Люди с разной целью стремятся уладить разногласия с помощью переговоров, будь это в политической сфере, в финансовых кругах или внутри семьи. Этим обусловлено стремление к изучению и активному обсуждению феномена переговоров. Важным становится осмысление сути деловой коммуникации и выделение ее отдельных характеристик и функций.

Английский язык получил особенно широкое распространение в мире переговоров благодаря интернационализации компаний, расширению международных контактов и глобализации бизнес-сообществ. Специфические характеристики переговорного дискурса конвенциональны и в целом регламентированы в языке $[1$, c. 180]. Мировой кинематограф зеркально отражает сформировавшиеся нормы и современные тенденции делового общения и емко реализует их в диалогах героев. Поскольку функция художественного фильма отражать действительность, реальность переговоров трансформирована и отражена через призму содержания и цели фильма.
«Переговоры - это сложный процесс, участники которого вступают в различные взаимоотношения, используя при этом, разные приемы влияния друг на друга» [3, с. 19]. Основой переговоров является сам переговорный процесс.

В научных работах исследователей выделяются несколько основных подходов к изучению и описанию переговорного процесса. К примеру, У. Юри и Р. Фишер анализируют переговоры как повседневное явление, дословно «факт нашей повседневной жизни» $[4$, с. 5]. Целью переговоров как повседневного действия, по мнению исследователей, является «достижение совместного решения». Схожих взглядов придерживался и У. Мастенбрук: он описывал переговорный процесс как тип поведения, применяемый в повседневной жизни, а не только в качестве специфической техники коммуникации. По мнению социолога, данный элемент присутствует в любой дискуссии [2, с. 175]. Следовательно, переговоры как тип общения являются фундаментальным процессом и влияют на состояние общественной жизни, ее развитие и изменение.

Коммуникация как социальное явление сопровожда- 
ет все виды человеческой деятельности. В целях подробного изучения деловых переговоров как коммуникативного процесса используются различные методы. Одной из моделей дискурсивного анализа является модель анализа процесса взаимодействия (АПВ) по Р. Бейлзу [5, с. 37]. В нее входят двенадцать категорий, представляющих собой простейшие законченные мысли, а именно:

1. В первую очередь, это выражение солидарности. В ситуации из эпизода фильма, где говорящий руководитель фирмы разговаривает с собеседником - сотрудницей, у которой в личной жизни появились трудности, из-за чего она хочет уменьшить график работы вдвое, но при этом оставить прежнюю заработную плату, руководитель поддерживает девушку и выражает взаимопонимание, пытаясь разделить ее проблему с помощью глагола "appreciate":

- I'm not saying that what you do isn't important. I appreciate you, and Liddy just adores you [13].

2. В той же ситуации мы наблюдаем выражение ослабления напряжения с помощью словосочетаний: "resolve fairly", "resolve amicably". Герой настроен решить проблему сотрудницы мягко и без конфликтов:

- I want to resolve this fairly and amicably [13].

3. Согласие чаще выражается прямым способом. Как, например, в следующей ситуации, где после непродолжительного торга покупатель прямо соглашается с ценой продавца:

- Okay. I'll pay \$450 per machine. \$450. On delivery, nothing up front [14].

4. Выражение предположения так же активно используется в процессе переговоров. В предложенной ниже ситуации адвокат, защищающий интересы фабрики, которая на самом деле действительно нанесла ущерб здоровью местных жителей, предполагает другие факторы, которые спровоцировали рост заболеваемости населения, что в последствие окажется ложной мыслью:

- A million things could have caused those problems. Poor diet, bad genes, irresponsible lifestyle. Our offer is final and it's more than fair [15].

5. Выражение мнения регулярно сопровождает объективные факты в речи, поскольку это персонализирует предложение и трансформирует его в более убедительное. В следующей реплике герой убеждает группу подростков притвориться, что они его дети, но получает отказ. В результате герой меняет тактику и делится своим мнением по поводу поведения их мамы в негативной окраске: "weird way", а также предполагает, какой интересной будет предлагаемая работа: "you'd be excited": - No, she's not like that. Your mother's presenting her in a weird, weird way. I'm just saying, telling the truth is not in the cards right now. I thought you'd be excited to have an acting job [16].
6. Выражение направления и дальнейшей ориентации. Это достаточно прямолинейный способ убедить собеседника сделать что-либо в интересах говорящего. В предложенной реплике переговорщик вместе с предлагаемыми уступками диктует террористу порядок действий:

- I'm gettin' you your car, but first things first. All right, Earl? We have to do this thing right. All right? Okay, Earl? I want you to take that gun and point it away from... What's your name, Miss? [16]

7. Запрос направления и дальнейшей ориентации в ниже предложенной реплике подталкивает слушающего дать положительный ответ и в дальнейшем совершить покупку:

- Shall I give you a little taste, young Ferdinand? [7]

8. Запрос мнения возможен в ситуациях, когда собеседник интересуется взглядом оппонента: - And what do you suggest I tell them? [8]

9. В отличии от запроса мнения запрос предположения выражает сомнение говорящего в происходящем, как, например, в следующей ситуации, когда солдаты офицера были взяты в плен, и герой не уверен в том, что порядок поведения с пленными со стороны оппонента был верным:

-To your mind, what are appropriate levels of hostile attention? [9]

10. Несогласие является одним из самых категоричных средств выражения мысли в процессе переговоров. В приведенном ниже примере мы видим критическую ситуацию, где адвокат принципиально отказывается обсуждать ситуацию:

- I cannot accept that. (she stands) There can be no settlement after I leave this office [10].

11. Выражение напряжения часто сопровождается дополнительными речевыми средствами, как интонация, парцелляция и другое. Например, в следующей реплике герой, чувствуя угрозу атаки, настойчиво просит не пересекать границу:

- Do - not - cross - this - stick [11].

12. Наконец, выражение антагонизма, противостояния. Состояние соперничества характерно для участников переговоров, поэтому выражение антагонизма можно считать самым распространенным в общении оппонентов. Например, в следующей ситуации два адвоката зеркально отражают атаки друг друга, чувствуя конкуренцию:

— Not to worry, Mrs. Rexroth. You're ably represented. I'm sure Freddy's just too modest to tell you he used to clerk for Clarence Thomas. Pastry? Going begging. - Don't try to bait me, Miles. If you have a proposal to make, let's hear it [12].

В результате мы можем сделать следующие выводы. Категории интеракции Р. Бейлза регистрируют различные взаимодействия между партнерами в переговорах, начиная с области взаимодействия, где доминируют положи- 
тельные эмоции и желание договориться, и заканчивая постановкой проблемы и выражением негативных чувств. В нашем анализе мы представили совокупность формы воздействия и оценкой причины выбора поведения на примере ситуаций из художественных англоязычных фильмов. Эмоциональное состояние героев и обстановка расширяют контекст категорий Р. Бейлза и демонстрирует широкий круг форм поведения в ситуации переговоров, что позволяет в будущем эффективно отстаивать свою позицию и успешно проводить переговоры.

\section{ЛИТЕРАТУРА}

1. Малюга Е.Н. Динамика развития теоретической базы межкультурной деловой коммуникации / Е.Н. Малюга// Вопросы лингвистики и лингводидактики иностранного языка делового и профессионального общения: Сборник материалов конференции. - М.: РУДН, 2008. — 180 с.

2. Мастенбрук В. Переговоры. Вильям Мастенбрук; Пер. с англ.: Дементьева Е.; Науч. ред.: Зайцев А. — Калуга: Калуж. ин-т социологии, 1993. — 175 с.

3. Резник С.Г. Всегда выигрывай деловые переговоры / С.Г. Резник. - Ростов-на-Дону: Феникс, 2006. — 190 с.

4. Фишер Р., Юри У. Путь к согласию или переговоры без поражения. — М.: Наука, 1992. — 160 c.

5. Firth A. The discourse of negotiations. Studies of language in the workplace / A. Firth (ed.). - Oxford: Pergamon, 1995. - $436 \mathrm{p}$.

6. «Городская полиция» («Metro», реж. Томас Картер, 1997).

7. «Звездная пыль» («Stardust», реж. Мэтью Вон, 2007).

8. «Мне бы в небо» («Up in the air», реж. Джейсон Райтман, 2009).

9. «Патриот» («The Patriot», реж. Ролланд Эмерих, 2000).

10. «Железная хватка» («True Grit», реж. Итан Коэн, 2010).

11. «Королевство полной луны» («Moonrise kingdom», реж. Уэс Андерсон, 2012).

12. «Невыносимая жестокость» («The Intolerable Cruelty», реж. Джоэль Коэн, 2003).

13. «Студия 30» («30 Rосk», реж. Дон Скардино, 2006-2013).

14. «Джобс: империя соблазна» («Jobs», реж. Джошуа Майкл Штерн, 2013).

15. «Эрин Брокович» («Erin Brockovich», реж. Стивен Содерберг, 2000).

16. «Притворись моей женой» («Just go with it», реж. Деннис Дуган, 2011).

() Шихалкина Татьяна Григорьевна (shikhalkina@gmail.com)

Журнал «Современная наука: актуальные проблемы теории и практики»

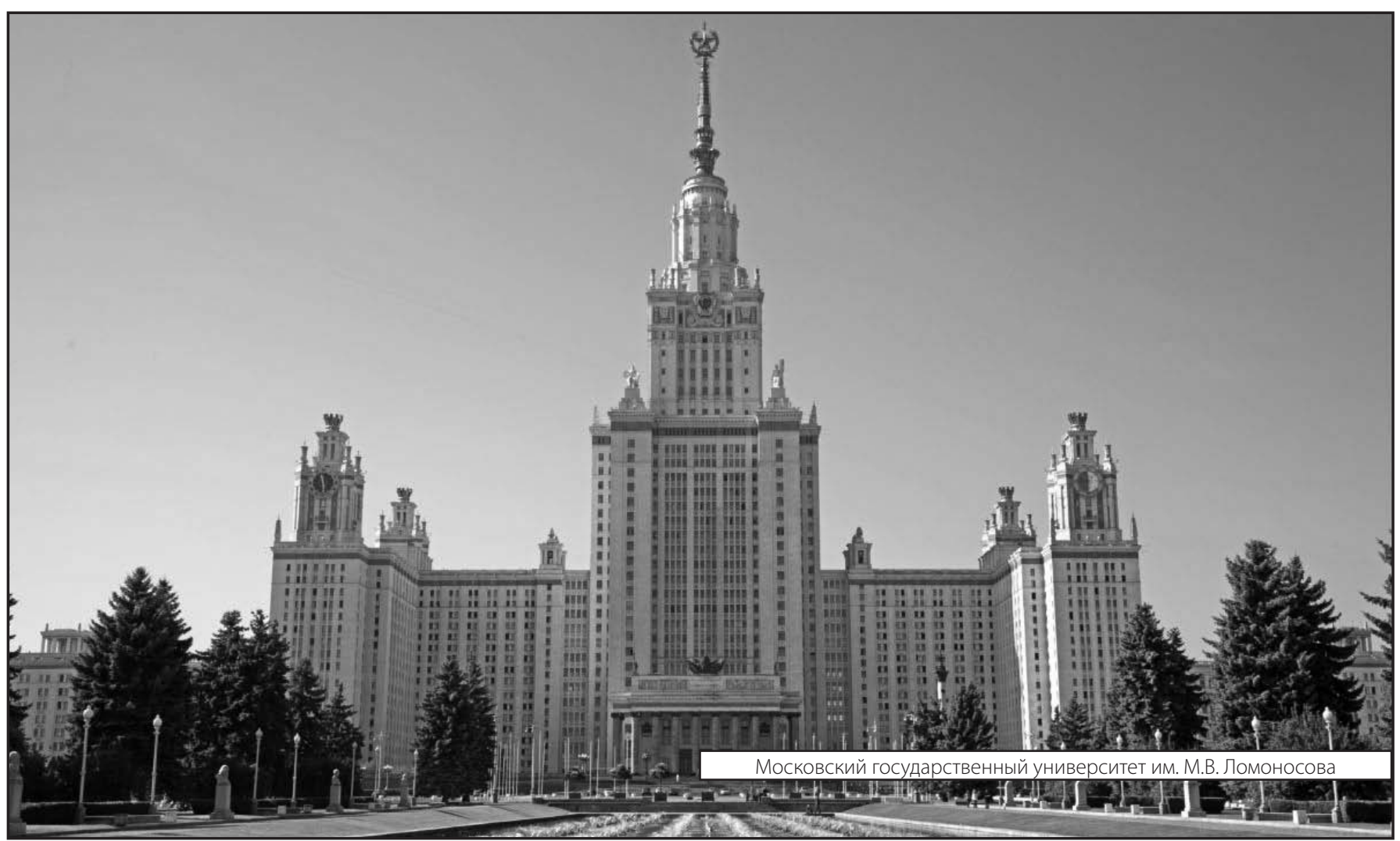

